\title{
Roles of Plant Proteases in Pathogen Defense
}

\author{
Kwang-Hyun Baek ${ }^{1 *}$ and Doil Choi ${ }^{2,3}$ \\ ${ }^{1}$ School of Biotechnology, Yeungnam University, Gyeongsan, Gyeongbuk 712-749, Korea \\ ${ }^{2}$ Dept. of Plant Sciences, Seoul National University, Seou1 151-742, Korea \\ ${ }^{3}$ Plant Genomics and Breeding Institute, Seoul National University, Seoul 151-742, Korea \\ (Received on August 11, 2008; Accepted on November 5, 2008)
}

\begin{abstract}
The genomes of plants contain more than 600 genes encoding a diverse set of proteases and the subunits of proteasomes. These proteases and proteasomes consist of plant proteolytic systems, which are involved in various cellular metabolic processes. Plant proteolytic systems have been shown to have diverse roles in defense responses, such as execution of the attack on the invading organisms, participation in signaling cascades, and perception of the invaders. In order to provide a framework for illustrating the importance of proteolytic systems in plant defense, characteristics of non-proteasome proteases and the $26 \mathrm{~S}$ proteasome are summarized. The involvement of caspase-like proteases, saspases, apoplastic proteases, and the $26 \mathrm{~S}$ proteasome in pathogen defense suggests that plant proteolytic systems are essential for defense and further clarity on the roles of plant proteases in defense is challenging but fundamentally important to understand plant-microbe interactions.
\end{abstract}

Keywords : defense, pathogen, plant proteases, proteasomes

Complex proteolytic systems in plants lead to the digestion of proteins into small peptides or amino acids (van der Hoorn, 2008). These systems perform the housekeeping function responsible for the removal of denatured proteins as well as for the adjustment of the stoichiometry of holoenzyme subunits (Buchanan et al., 2002). At least 723 and 955 putative protease genes have been identified within the genome of Arabidopsis and Populus, respectively (Garcia-Lorenzo et al., 2006). More and more additional proteases have been identified by in silico analysis, and in the review of van der Hoorn (2008), the number of protease genes in Arabidopsis genome increase to 826 from 488 (van der Hoorn and Jones, 2004).

The proteolytic enzymes are commonly termed proteases, proteinases, or peptidases. In this review, the term "proteases" is chosen. The proteolytic systems in plants include (i) proteases and (ii) proteasomes. Proteases are divided into five classes based on the amino acid determinants of

\footnotetext{
*Corresponding author.

Phone) +82-53-810-3029, FAX) +82-53-810-4769

E-mail)khbaek@ynu.ac.kr
}

their catalytic site or their required metal cofactors, such as serine protease (EC 3.4.21), cysteine protease (EC 3.4.22), aspartic endopeptidase (EC 3.4.23), metalloprotease (EC 3.4.24), and threonine protease (EC 3.4.25) (Table 1) (Barrett et al., 2004). The catalytic classes are subdivided into Clans, and the Clans are further subdivided into Families based on the evolutionary relationship. An extremely useful updated site for classification and information on all known proteases can be found in the MEROPS database (http://merops.sanger.ac.kr) (Rawlings and Barrett, 1999; Rawlings et al., 2006).

In addition to the primary role of plant proteolytic systems in degrading nonfunctional proteins, the systems have been shown to be involved in various processes in response to developmental and environmental cues (Dreher and Callis, 2007; van der Hoorn, 2008). The high level of substrate-specificity and the tight regulation of temporal and spatial enzymatic activity imply that plant proteolytic systems are key regulators for cellular metabolism, such as development, cell cycle, cell growth and defense (van der Hoorn, 2008). Interestingly, studies have revealed that various proteolytic systems actively participate in the plant defense against pathogens (Table 2) (Dreher and Callis, 2007; van der Hoorn and Jones, 2004). The effects of proteases can be seen at different levels including: i) pathogen recognition, ii) the induction of defense responses, iii) signals leading to the release of positive regulators, iv) the degradation of negative regulators, or $v$ ) the execution of defense responses (van der Hoorn and Jones, 2004).

In this review, we summarize recent advances in the functional analysis of plant non-proteasomal proteases and the $26 \mathrm{~S}$ proteasome playing important roles in plantmicrobe interactions and defense. Each of these sets of proteolytic systems can be found at different sets of subcellular locations (Fig. 1). In addition to the $26 \mathrm{~S}$ proteasome, several non-proteasomal proteases are chosen for the discussion of the role of proteases in defense, including caspase-like proteases in vacuole and saspases in cytosol as well as cysteine proteases, aspartic proteases and the matrixins in apoplasts. 
Table 1. Classification of proteases based on their catalytic funtions

\begin{tabular}{lcccc}
\hline Catalytic type & Active site & Synonyms & Clans & Characteristics \\
\hline Aspartic proteases & Aspartate & $\begin{array}{c}\text { Acid protease } \\
\text { Aspartate protease }\end{array}$ & AA, AB, AC, AD, AF & $\begin{array}{c}\text { All endopeptidases, e.g., } \\
\text { pepsin }\end{array}$ \\
\hline Cysteine proteases & Cysteine & $\begin{array}{c}\text { Thiol proteinase, } \\
\text { Sulfhydryl protease }\end{array}$ & CA, CD, CE, CF, CH, 'CX' & e.g., Papain family \\
Metallo-proteases & Metal cofactors & Metallopeptidase & $\begin{array}{c}\text { MA, MC, MD, ME, MD, MJ, ML, } \\
\text { MM, M11, MF, MG, MH, MN }\end{array}$ & $\begin{array}{c}\text { Divalent metal cations, } \\
\text { e.g , Co, Mn, Ni or Cu, } \\
\text { mostly Zn-dependent }\end{array}$ \\
\hline Serine proteases & Serine & PA(S), SB, SC, SE, SF, & SH, SK, SM, SN & \\
\hline Threonine protease & Threonine & & & $\begin{array}{c}\text { Prototype members are } \\
\text { the proteasome catalytic subunits }\end{array}$ \\
\hline
\end{tabular}

\section{Roles of Plant Non-proteasomal Proteases in Patho- gen Defense}

Plant proteolytic systems are consisted of proteases and proteasomes. Proteasomes found in cytosol and in nucleus are multiunit complex, therefore, in this review, we summarizes the non-proteasomal proteases first. Caspase-like proteases and saspases are chosen to help explain the role of proteases in hypersensitive response (HR) to incompatible microbial pathogen attack. We also review the functions of extracellular secreted proteases in pathogen defense. The extracellular space is the interface of host-pathogen interaction and considered to be the molecular battlefield between plants and phytopathogens. The secreted extracellular proteases are the key players of plant defense at apoplasts and the summarized apoplastic proteases include i) papainlike cysteine proteases, ii) aspartic proteases, and iii) matrixins.

\section{Caspase-like proteases implicated in plant defense} (Clan CD). Caspases are the principal players for apoptosis in animal cells (Grütter, 2000). In animals, programmed cell death (PCD) can be classified into two categories, caspase-dependent or caspase-independent (van Doorn and Woltering, 2004). The key components of apoptotic cell death in animals are the caspases, a family of cysteine proteases which exist as dormant proenzymes in the cytosols of most cells. During apoptosis, a battery of caspases become activated through proteolytic processing at internal aspartic acid residues. The action of the active caspases on their substrates causes apoptotic morphological changes and eventually cell death.

Although caspase activities have been reported in plants for over 10 years, plants do not have orthologous sequences to animal caspase genes in their genome (Bonneau et al., 2008). Two families of caspase-like proteases are identified as paracaspases and metacaspases by in silico genome

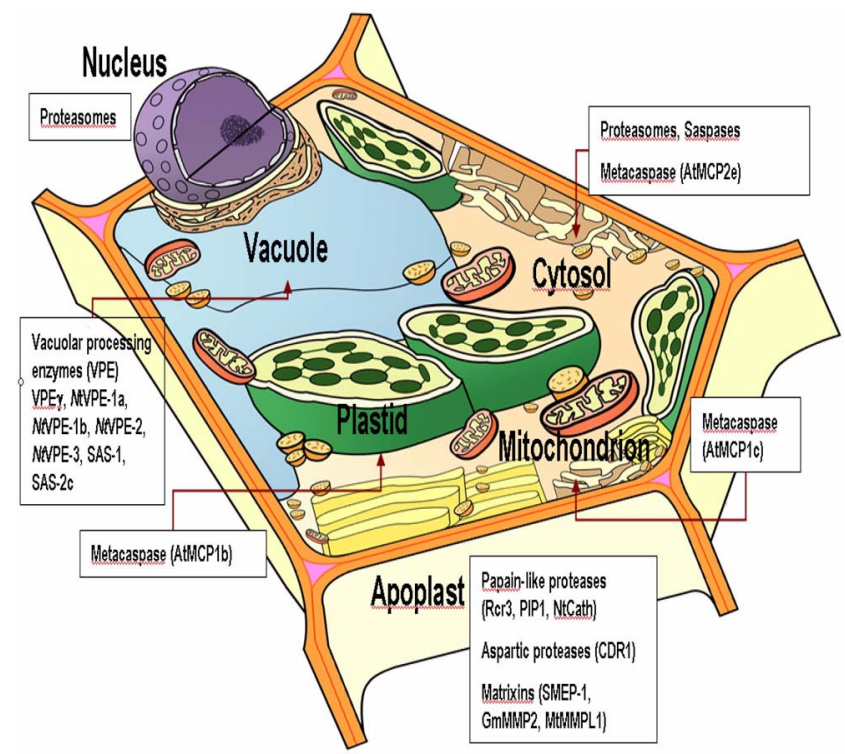

Fig. 1. Subcellular localizations of the proteases and proteasomes involved in pathogen defense.

analysis (Uren et al., 2000). Paracaspases and caspases are present in animals, whereas metacaspases (MCPs) are found in plants, fungi, and protozoa. Plant metacaspases (family C14) are classified into type I and II, based on sequence and structural similarities. In the Arabidopsis genome, nine $M C P$ s have been identified, two of which are upregulated by bacterial pathogens (Watanabe and Lam, 2004). In tomato, a metacaspase gene was upregulated following the infection of Botrytis cinerea (Hoeberichts et al., 2003). Single knock-out mutants of Arabidopsis metacaspases 2-6 were slightly but significantly less susceptible than wild-type to $B$. cinerea and $B$. tulipae, but not to $B$. elliptica (Van Baarlen et al., 2007). Plant metacaspases were suspected to have caspase-like activities (Madeo et al., 2002), however, they do not cleave caspase substrates ( $\mathrm{He}$ et al., 2007; Watanabe and Lam, 2005). More studies are 
Table 2. Pathogen-responsive proteases referred in this study.

\begin{tabular}{|c|c|c|c|c|c|c|c|}
\hline Divisions $^{\mathrm{a}}$ & $\begin{array}{l}\text { Groups of } \\
\text { proteases }\end{array}$ & $\begin{array}{l}\text { Catalytic } \\
\text { types }\end{array}$ & Subclasses & $\begin{array}{l}\text { Names of } \\
\text { genes }\end{array}$ & Plant species & Pathogens or elicitors & References \\
\hline \multirow{5}{*}{$\begin{array}{l}\text { Caspase-like } \\
\text { proteases }\end{array}$} & \multirow{4}{*}{$\begin{array}{l}\text { Caspase-like } \\
\text { proteases }\end{array}$} & \multirow{4}{*}{$\begin{array}{l}\text { Cysteine } \\
\text { proteases }\end{array}$} & \multirow[t]{2}{*}{$\begin{array}{l}\text { Meta- } \\
\text { caspases }\end{array}$} & $\begin{array}{l}A t \mathrm{MCP} 1 \mathrm{~b} \\
A t \mathrm{MCP} 1 \mathrm{c}, \\
A t \mathrm{MCP} 2 \mathrm{e}\end{array}$ & A. thaliana & $\begin{array}{c}\text { Pseudomonas infestanse, } P \text {. } \\
\text { syringae pv phaseolicola, } \\
\text { P. syringae pv tomato } \\
\text { DC } 3000\end{array}$ & $\begin{array}{l}\text { Wanatabe and Lam } \\
\text { (2004) } \\
\text { Sanmartín et al. (2005) }\end{array}$ \\
\hline & & & & LeMCA1 & S. lycopersicum & Botrytis cinerea & $\begin{array}{l}\text { Hoeberichts et al. } \\
\text { (2003) }\end{array}$ \\
\hline & & & \multirow{2}{*}{$\begin{array}{l}\text { Vacuolar } \\
\text { processing } \\
\text { enzymes } \\
\text { (VPE) }\end{array}$} & VPE $\gamma$ & A. thaliana & $\begin{array}{l}\text { P. syringae, } B . \text { cinerea, } \\
\text { and turnip mosaic virus }\end{array}$ & Rojo et al. (2004) \\
\hline & & & & $\begin{array}{l}N t \text { VPE-1a, } \\
N t \text { VPE- } 1 \mathrm{~b}, \\
N t \text { VPE- } 2 \\
N t \text { VPE-3 }\end{array}$ & $N$. benthamiana & Tobacco mosaic virus & Hatsugai et al. (2004) \\
\hline & Saspases & $\begin{array}{c}\text { Serine } \\
\text { proteases }\end{array}$ & & SAS-1,SAS-2 & A. sativa & $\begin{array}{l}\text { Victorin from Cochliobolus } \\
\text { victoriae }\end{array}$ & $\begin{array}{l}\text { Navarre and Wolpert } \\
\text { (1999), Coffeen and } \\
\text { Wolpert (2004) }\end{array}$ \\
\hline \multirow{7}{*}{$\begin{array}{l}\text { Apoplastic } \\
\text { proteases }\end{array}$} & \multirow{4}{*}{$\begin{array}{l}\text { Papain-like } \\
\text { proteases }\end{array}$} & \multirow{4}{*}{$\begin{array}{l}\text { Cysteine } \\
\text { proteases }\end{array}$} & & $\begin{array}{l}\text { Rcr3 } \\
\text { PIP1 }\end{array}$ & S. lycopersicum & $\begin{array}{c}\text { Cladosporium fulvum } \\
\text { P. infestans }\end{array}$ & $\begin{array}{l}\text { Krüger et al. (2002) } \\
\text { Tian et al. (2007) }\end{array}$ \\
\hline & & & & $\begin{array}{l}N b \text { CYP1, } \\
N b \text { CYP2 }\end{array}$ & N. benthamiana & $\begin{array}{l}\text { Colletotrichum destructi- } \\
\text { vum }\end{array}$ & Hao et al. (2006) \\
\hline & & & & $N t$ Cath & N. benthamiana & Erwinia carotovora & Gilroy et al. (2007) \\
\hline & & & & StCath & S. tuberosum & P. infestans & $\begin{array}{l}\text { Avrova et al. (1999, } \\
\text { 2004) }\end{array}$ \\
\hline & $\begin{array}{l}\text { Aspartic } \\
\text { proteases }\end{array}$ & $\begin{array}{l}\text { Aspartic } \\
\text { proteases }\end{array}$ & & CDR1 & A. thaliana & P. syringae & Xia et al. (2004) \\
\hline & \multirow[t]{2}{*}{ Matrixins } & \multirow{2}{*}{$\begin{array}{l}\text { Metallo- } \\
\text { proteases }\end{array}$} & & GmMMP2 & G. $\max$ & $\begin{array}{l}\text { Phytophthora sojae or } \\
\text { P. syringae pv glycinae }\end{array}$ & Liu et al. (2001) \\
\hline & & & & MtMMPL1 & M. truncatula & Sinorhizobium meliloti & Combier et al. (2007) \\
\hline Proteasomes & & & & $\begin{array}{c}\beta 1-\operatorname{tcI} 7, \alpha 3, \\
\alpha 6\end{array}$ & N. tabacum & $\begin{array}{l}\text { Cryptogein secreted by } \\
\text { Phytophthora cryptogea }\end{array}$ & $\begin{array}{l}\text { Petitot et al. (1997), } \\
\text { Dahan et al. (2001) }\end{array}$ \\
\hline
\end{tabular}

${ }^{a}$ Divisions mean the primary divided protease groups used in this review.

needed to elucidate the roles of plant metacaspases in defense, especially in regulating HR.

The plant vacuolar processing enzymes (VPE in family C13) are cysteine proteases, which were unexpectedly proven to have caspase-1 like activity and required for the HR in response to tobacco mosaic virus (TMV) (Hatsugai et al., 2004). Specifically, the mRNA and protein levels of four VPE cDNAs isolated from Nicotiana benthamiana were rapidly and transiently increased during early stages of HR in the TMV-infected tobacco leaves (Hatsugai et al., 2004). VPE-silenced $N$. benthamiana showed no visible lesions by TMV inoculation. The transcription of one of these genes (VPE $\gamma$ ) is induced by the infection with Pseudomonas syringae, B. cinerea, and turnip mosaic virus (Rojo et al., 2004). Knockout of VPE $\gamma$ in Arabidopsis results in increased susceptibility to these pathogens, suggesting that VPEs contribute not only to resistance to incompatible pathogens but also to the plant basal defense to compatible pathogens (Rojo et al., 2004). A fungal toxin fumonisin B1 induced cell death of Arabidopsis, however, in Arabidopsis VPE-null mutants lacking all four VPE genes, the features of cell death induced by fumonisin B1 were completely abolished (Kuroyanagi, 2005). No structural similarity between VPEs and caspases exists but the caspase-1 activity of VPE suggests that plants have evolved a novel cellular suicide mechanism using VPE and the cellular vacuole.

Saspase, a serine protease with caspase-like activity implicated in plant defense (Clan SB). The sensitive Avena sativa leaves treated with the victorin toxin from necrotrophic fungus Cochliobolus victoriae show symptoms of PCD (Navarre and Wolpert, 1999). Two proteases involved in the victorin-induced PCD signaling cascade 
were purified and characterized (Coffeen and Wolpert, 2004). These proteases have caspase activity and belong to the family of plant subtilisin-like serine proteases (Bonneau et al., 2008; Sanmartín et al., 2005). Interestingly, these proteases have distinct substrate specificities compared to all other known subtilisin-like serine proteases. Saspase was coined because of their aspartate specificity (aspase) and active-site serine residue (S) of those proteases. Saspases are constitutively expressed in cells in an active form and appear to function in the apoplasts. A Kazal-like extracellular serine protease inhibitor from Phytophthora infestans suppresses host cell death, and may target plant saspases to mediate this activity (Tian et al., 2004). A serine protease (Kunitz trypsin) inhibitor is triggered by phytopathogens and fumonisin B1 in Arabidopsis, and it antagonizes PCD in plant-pathogen interactions ( $\mathrm{Li}$ et al., 2008). Although the mode of inhibition strongly suggests that the target proteases are saspases, the mode of action of cell death modulation and the target protease(s) have yet to be elucidated ( $\mathrm{Li}$ et al., 2008).

Apoplastic proteases implicated in plant defense. Plant apoplasts are the interface between the plant and the interacting microenvironments. Plant cells secrete constitutively expressed proteins and inducible proteins involved in defense into apoplasts. Apoplasts interact with biotic and abiotic stresses, handle pathogen attacks, and effectively modulate the cellular metabolism (Agrios, 2005). Apoplasts provide a crucial defense against microbial pathogen attacks, and therefore can be described as a molecular battlefield for surveillance, assault, defense, and counter-defense (Lee et al., 2006). More than $50 \%$ of all proteases are predicted to be secreted into the apoplasts or into vacuoles as determined by our in silico tomato cDNA analysis (unpublished data). Therefore, clarifying the role of apoplastic proteases in pathogen defense will be a key step in understanding the plant-microbe interactions at the molecular battlefield.

Apoplastic papain-like cysteine proteases implicated in plant defense (ClanCA, C1A family). Papain is a small cysteine protease found in the latex of papaya trees, which has broad substrate specificity and plays an important role in defense (El Moussaoui et al., 2001). Multigenes of papain-like cysteine proteases (PLCPs), which share amino acid sequence homology and order of catalytic residues with papain, have been characterized in many plant species and known to have important roles in plant defense against microbial pathogens (Shabab et al., 2008). PLCPs, usually between 23-30 kDa, contain a cysteine residue at the catalytic site capable of cleaving peptide bonds in target proteins (Shindo and van der Hoorn, 2008). PLCPs have been grouped in the family $\mathrm{C} 1$, which has been further subdivided into: i) apoplastic PLCPs (subfamily C1A) and ii) cytoplasmic PLCPs (subfamily C1B) in the MEROPS database. Many of the apoplastic PLCPs are induced by pathogen attack, and are part of a defense layer in the apoplastic battlefield.

The tomato apoplasts contain seven PLCPs classified into four different subfamilies (Shabab et al., 2008). Among the PLCPs, transcripts of Rcr3 (Required for Cladosporium resistance- $\underline{3}$ ) and Pipl (Phytophthora inhibited protease- $\underline{1}$ ) are up-regulated upon pathogen attack, and accumulate in the apoplasts (Krüger et al., 2002; Tian et al., 2007). Treatment with benzothiazole, which triggers the salicylic acidregulated defense response, induces only the transcripts of Rcr 3 and PIP 1, suggesting the regulation of the genes by salicylic acid (Shahab et al., 2008). Rcr3 is required for the function of the tomato $\mathrm{Cf}-2$ receptor-like protein against the fungal pathogen Cladosporium fulvum carrying the Avr2 avirulence gene (Krüger et al., 2002). However, the secreted Avr2, a cysteine-rich protein, binds and inhibits Rcr3, suggesting that Rcr3 is rather a virulence target of Avr2 that is guarded by the $\mathrm{Cf}-2$ resistance protein to monitor pathogen entry (Jones and Dangl, 2006; Luderer et al., 2002; Rooney et al., 2005). PIP1 is a pathogenesis-related protein closely related to Rcr3. PIP1 is inhibited by Epic2B, a cystatin-like protease inhibitor secreted during infection by P. infestans (Tian et al., 2007). The PIP1 and Rcr 3 genes map to the same locus of the tomato genome (Shido and van der Hoorn, 2008), however, the higher accumulation of PIP1 protein levels when compared to Rcr3 indicates that PIP1 might be the real virulence target of Avr2 while Rcr3 act as a decoy for Avr2 perception in plants carrying the Cf2 resistance gene (Jones and Dangl, 2006; Shabab et al., 2008). However, still the mode of how Avr2 and Epic2B specifically inhibit PLCPs and of how Cf-2 recognizes the Rcr3-Avr2 complex remains unclear (Shindo and van der Hoorn, 2008).

In $N$. benthamiana, two PLCPs, $N b C Y P 1$ and $N b C Y P 2$, are differentially expressed during the susceptible response to Colletotrichum destructivum but not the resistant response to $P$. syringae pv. tomato (Hao et al., 2006). Virusinduced gene silencing (VIGS) of the two genes indicate that these PLCPs are not involved in the HR to P. syringae pv. tomato, but they are involved in limiting the host susceptibility to $C$. destructivum (Hao et al., 2006). $N$. benthamiana cathepsin B is an apoplastic PLCP, activated upon secretion in the absence of pathogen challenge, and required for disease resistance (Gilroy et al., 2007). VIGS of cathepsin B prevented PCD and compromised disease resistance induced by Erwinia amylovora and $P$. syringae pv. tomato DC3000, two non-host bacterial pathogens to tobacco (Gilroy et al., 2007). In Solanum tuberosum, StCath, a PLCP is also known as rapidly induced during R 
gene-mediated potato interactions with $P$. infestans (Avrova et al., 1999; 2004).

Plant cystatins, cysteine protease inhibitors, show strong papain-inhibitory activities (Li et al., 1996). AtCys 1 (Arabidopsis cystatin-1) is strongly induced by wounding, challenge with avirulent pathogens, or by nitric oxide (Belenghi et al., 2003). The overexpression of AtCYS1 blocks cell death caused by the infection of avirulent $P$. syringae (Belenghi et al., 2003). The inhibition of the PLCP enzymatic activity and of HR cell death by cystatins indicates that complex interactions between PLCPs and cystatins in apoplasts regulate the induction of $\mathrm{HR}$ and the spread of pathogens.

\section{Apoplastic aspartic protease CDR1 implicated in plant} defense (Clan AA, Family A1). The gene product of $A$. thaliana constitutive disease resistance 1 (CDR1) is an apoplastic aspartic protease and is a member of a larger group of the atypical aspartic protease (Simões et al., 2007). The overexpression of CDR1 causes dwarfing and resistance to virulent $P$. syringae, and the suppression of CDR1 results in compromised resistance to avirulent $P$. syringae and in increased susceptibility to virulent strains compared to the wild type. The role of CDR1 in defense is proposed to mediate the generation of an endogenous peptide signal involved in the activation of inducible resistance mechanisms (Xia et al., 2004).

Matrixins (or matrix metalloendopeptidases) implicated in plant defense (Clan MA(M), family M10A). The extracellular matrix (ECM) is a complex structural entity surrounding and supporting cells and is composed of structural proteins, specialized proteins and proteoglycans (Roberts, 1994). Matrixins are the proteases degrading and remodeling the structural proteins within the ECM (Barett et al., 2004). Matrixins are synthesized as prepro-enzymes and contain a signal peptide targeting them to the apoplast (Nagase and Woessner, 1999). The pro-matrixins are most likely activated proteolytically by certain groups of proteases in vivo as well as by mercurial compounds and reactive oxygen in vitro (Nagase and Woessner, 1999). Studies of matrixins in vertebrates revealed their role in development, embryogenesis, organ morphogenesis, and wound healing, as well as in pathological processes such as cancer and arthritis (Barett et al., 2004). The studies with animal matrixins suggest that plant matrixins may be essential regulators of growth and development and even have an important role for plant defense and PCD.

Several matrixins were isolated from plants, including soybean (Graham et al., 1991; Liu et al., 2001; McGeehan et al., 1992; Pak et al., 1997), Arabidopsis (Maidment et al., 1999), cucumber (Golldack et al., 2002), and alfalfa
(Combier et al., 2007). Matrixins hold the HEX2HX2GX2HS zinc-binding catalytic motif and are sensitive to EDTA (McGeehan et al., 1992). The first isolated matrixin from higher plants was SMEP-1 (soybean metalloendoproteinase-1) from soybean (Graham et al., 1991), and is localized to the apoplasts of leaves. SMEP-1 showed both structural and biochemical similarities with vertebrate matrixins (McGeehan et al., 1992). The M10A family of vertebrate matrixins includes a number of proteases, such as collagenases, gelatinases, stromalysins, and matrilysin, etc. (Barrett et al., 2004).

GmMMP2, the second matrixin from soybean was identified as a gene which is transcriptionally upregulated during compatible and incompatible interactions with the oomycete pathogen Phytophthora sojae or the bacterial pathogen P. syringae pv glycinae, suggesting that it may be involved in a novel defense mechanism (Liu et al., 2001). Interestingly, GmMMP2 is not induced by the classical pathogeninduced signaling molecules such as salicylic acid and jasmonic acid, and furthermore does not correlate with the oxidative burst leading to HR (Liu et al., 2001). MtMMPL1, a Medicago truncatula matrixin represents a novel and specific marker for root and nodule infection by Sinorhizobium meliloti (Combier et al., 2007). The loss-of-function study employing an RNA interference approach to decrease MtMMPL1 expression revealed an accumulation of Rhizobia within infection threads, often accompanying significantly enlarged diameter of the threads. The overexpression of MtMMPL1 in a gain-of-function study resulted in numerous abortive infections and an overall decrease in the number of nodules (Combier et al., 2007). Although the roles of plant M10A matrixins are not yet fully understood, plant matrixins seem to be involved in a novel defense mechanism and may even be involved in plant PCD.

\section{Roles of the Plant 26S Proteasome in Pathogen Defense}

Most cytoplasmic and nuclear proteins are degraded in a ubiquitin (Ub) and $26 \mathrm{~S}$ proteasome-mediated manner (Delauré et al., 2008). The non-lysosomal intracellular protein degradation mediated by this pathway is essential for the regulation of various cellular processes, such as development, cell cycle, cell growth, and transcription (Jesenberger and Jentsch 2002). The 76-amino acid protein $\mathrm{Ub}$ is attached to proteins destined for degradation, and then the resulting Ub-protein conjugates are tagged for catalization by the $26 \mathrm{~S}$ proteasome (Smalle and Vierstara, 2004). The $26 \mathrm{~S}$ proteasome contains 31 principal subunits and is composed of a $20 \mathrm{~S}$ core proteasome and a $19 \mathrm{~S}$ regulatory particle (Beers et al., 2000). Association of the 20S core proteasome with the multisubunit $19 \mathrm{~S}$ regulatory particle creates the ATP-dependent, 2,100 $\mathrm{kDa}, 26 \mathrm{~S}$ proteasome 
(Samlle and Vierstra, 2004). Recently, evidence is heavily accumulating which suggests that the ubiquitin/proteasome pathway may control a range of cellular signaling processes in plants, such as those mediated by hormones, light and sucrose, as well as development and response to pathogens (Ellis et al., 2002; Smalle and Vierstara, 2004). The ubiquitin cascade is operated sequentially in a multi-step fashion by a multi-enzymatic system, consisting of ubiquitin-activating (E1), -conjugating (E2), and -ligating (E3) enzymes (Delauré et al., 2008; Glickman and Ciechanover, 2002). E3 ubiquitin ligases mediate the final transfer of ubiquitin to the target proteins, and therefore, they represent an important portion of the degradation process. Increasing numbers of studies illustrate the involvement of E3 ubiquitin ligases in plant defense (Kuprea and Smalle, 2008). More than 1,300 genes encoding for a E3 ubiquitin ligase motif are present in the Arabidopsis genome (Kraft et al., 2005). The E3 ubiquitin ligases can be classified in two major groups: those containing a HECT (for homology to E6-associated protein $\underline{\mathrm{C}}$-terminus) domain and those with a RING (really interesting new gene) or RING-like (called U-box) domain. The in silico analyses on the expression of all annotated E3 ubiqutin ligase components reveal that biotic stress induces up-regulation and down-regulation of up to 548 and 382 E3 ubiquitin ligase components, respectively (Delauré et al., 2008). E3 ubiquitin ligases and the related protein breakdown have been shown to play an important role in the signal transduction pathways leading to disease resistance (Delauré et al., 2008; Devoto et al., 2003; Dreher and Callis 2007). E3 ubiquitin ligases are involved in plant defenses by controlled proteolysis in i) 'gene-for-gene' disease resistance, ii) early defense response reactions and iii) late induced defense responses (Delauré et al., 2008; Read Dreher and Callis, 2007, and Delauré et al., 2008 to get more detailed information).

Proteasomes are known to be involved in the plant defense in response to pathogen attacks (Dahan et al., 2001; Groll et al., 2008; Kurepa et al., 2008). Specifically, competence development was greatly suppressed by specific inhibitors of proteasome activity in cucumber hypocotyls (Becker et al., 2000). Treatment with cryptogein, a proteinaceous elicitor of plant defense reactions induced the upregulation of only the genes encoding b1-tcI 7, $\alpha 3$ and $\alpha 6,20 \mathrm{~S}$ proteasome subunits in tobacco (Petitot et al., 1997; Dahan et al., 2001). The defense-induced (din) $20 \mathrm{~S}$ subunits are induced only in the conditions of the induction of systemic acquired resistance and of the production of reactive oxygen species (Suty et al., 2003). Production of reactive oxygen species in tobacco plants treated with cryptogein is mediated by the NADPH oxidase and triggers the accumulation of $\beta 1$ din $20 \mathrm{~S}$ subunits (Lequeu et al., 2005). Gain- or loss- of functional studies for the $\beta 1$ din
$20 \mathrm{~S}$ subunits demonstrate that a proteasome composed of a $\beta 1$ din $20 \mathrm{~S}$ subunit acts as a negative regulator of NADPH oxidase during the elicitation of plant defense reactions, and in this manner contributes to the regulation of ROS generation during the pathogen attack (Lequeu et al., 2005).

\section{Conclusions and Perspectives}

There have been massive accumulations of exciting reports on the crucial involvement of plant proteolytic systems on pathogen defense. The study of the proteolytic systems on pathogen defense will be very challenging due to the huge numbers of proteases, their redundancy, cellular locations, activation mechanism, and substrates variances. However, considering the roles of proteolytic systems in perception, signaling, and execution leading to plant defense (van der Hoorn and Jones, 2004), elucidation of the functions of these diverse proteolytic systems in defense will be one of the most important studies for understanding the interaction between plants and pathogens. In the next decades, further advances will provide astonishing discoveries on the roles of plant proteolytic systems in defense by combining the newly advancing functional genomics and proteomics with the studies determining the substrates for the candidate proteases or proteasomes.

\section{Acknowledgments}

This research was supported by the Yeungnam University Research Grants in 207-A-054-034 to K.-H. Baek and by the Seoul National University Research Grants in 5002006018 to D. Choi. We appreciate Mr. Jinkyu Chae for the Figure 1 illustration.

\section{References}

Agrios, G. N. 2005. Plant Pathology, $5^{\text {th }}$ Ed., Elservier Academic Press, San Diego.

Avrova, A. O., Stewart, H. E., De Jong, W., Heilbronn, J., Lyon, G.D. and Birch, R. R. J. 1999. A cysteine protease gene is expressed early in resistant potato interactions with Phytophthora infestans. Mol. Plant Microbe Interact. 12:1114-1119.

Avrova, A. O., Taleb, N., Rokka, V. M., Heilbronn, J., Campbell, E., Hein, I., Gilroy, E. M., Cardle, L., Bradshaw, J. E. and Stewart, H. E. 2004. Potato oxysterol binding protein and cathepsin B are rapidly up-regulated in independent defence pathways that distinguish $\mathrm{R}$ gene-mediated and field resistances to Phytophthora infestans. Mol. Plant Pathol. 5:45-56.

Barrett, A. J., Rawlings, N. D. and Woessner J. F. (eds.). 2004. Handbook of Proteolytic Enzymes, Elservier Academic Press, London.

Becker, J., Kempf, R., Jeblick, W. and Kauss, H. 2000. Induction of competence for elicitation of defense responses in cucumber hypocotyls requires proteasome activity. Plant J. 21:311- 
316.

Beers, E. P., Woffenden B. J. and Zhao, C. 2000. Plant proteolytic enzymes: possible roles during programmed cell death. Plant Mol. Biol. 44:399-415.

Belenghi, B., Acconcia, F., Trovato, M., Perazzolli, M., Bocedi, A., Polticelli, F., Ascenzi, P. and Delledonne, M. 2003. A cystatin from Arabidopsis thaliana, suppresses hypersensitive cell death. Eur. J. Biochem. 270:2593-2604.

Bonneau, L., Ge, Y., Drury, G. E. and Gallois, P. 2008. What happened to plant caspases? J. Exp. Bot. 59:491-499.

Buchanan, B. B., Gruissem, W. and Jones, R. L. 2002. Biochemistry and Molecular Biology of Plants. American Society of Plant Physiologists, Rockville, p. 447.

Coffeen, W. C. and Wolpert, T. J. 2004. Purification and characterization of serine proteases that exhibit caspase-like activity and are associated with programmed cell death in Avena sativa. Plant Cell 16:857-873.

Combier, J. P., Vernié, T., De billy, F., El yahyaoui, F., Mathis, R. and Gamas, P. 2007. The MtMMPL1 early nodulin is a novel member of the matrix metalloendoproteinase family with a role in Medicago truncatula infection by Sinorhizobium meliloti. Plant Physiol. 144:703-716.

Dahan, J., Etienne, P., Petitot, A. S., Houot, V., Blein, J. P. and Suty, L. 2001. Cryptogein affects expression of $\alpha 3, \alpha 6$ and b1 20S proteasome subunits encoding genes in tobacco. J. Exp. Bot. 52:1947-1948.

Delauré, S., Van Hemelrijck, W., De bolle, M., Cammue, B. and De coninck, B. 2008.

Building up plant defense by breaking down proteins. Plant Sci. 174:375-385.

Devoto, A., Muskett, P. R. and Shirasu, K. 2003. Role of ubiquitination in the regulation of plant defence against pathogens. Curr. Opin. Plant. Biol. 6:307-311.

Dreher, K. A. and Callis, J. 2007. Ubiquitin, hormones and biotic stress in plants. Ann. Bot. 9: 787-822.

Ellis, C., Turner, J. G. and Devoto, A. 2002. Protein complexes mediate signalling in plant responses to hormones, light, sucrose and pathogens. Plant Mol. Biol. 50:971-980.

El Moussaoui A., Nijs, M., Paul, C., Wintjens, R., Vincentelli, J., Azarkan, M. and Looze, Y. 2001. Revisiting the enzymes stored in the laticifers of Carica papaya in the context of their possible participation in the plant defence mechanism. Cell Mol. Life Sci. 58:556-570.

García-Lorenzo, M., Sjödin, A., Jansson, S. and Funk, C. 2006. Protease gene families in Populus and Arabidopsis. BMC Plant Biol. 6:30.

Gilroy, E. M., Hein, I., van der Hoorn, R., Boevink, P. C., Venter, E., McLellan, H., Kaffarnik, F., Hrubikova, K., Shaw, J., Holeva, M., López, E. C., Borras-Hidalgo, O., Pritchard, L., Loake, G. J., Lacomme, C. and Birch, P. R. 2007. Involvement of cathepsin B in the plant disease resistance hypersensitive response. Plant J. 52:1-13.

Glickman, M. H. and Ciechanover, A. 2002. The ubiquitin-proteasome proteolytic pathway: destruction for the sake of construction. Physiol. Rev. 82:373-428.

Golldack, D., Popova, O. V. and Dietz, K. J. 2002. Mutation of the matrix metalloproteinase At2-MMP inhibits growth and causes late flowering and early senescence in Arabidopsis. $J$. Biol .Chem. 277:5541-5547.

Graham, I. A., Xiong, J. and Gillikin, J. W. 1991. Purification and developmental analysis of a metalloproteinase from the leaves of Glycine max. Plant Physiol. 97:786-792.

Groll, M., Schellenberg, B., Bachmann, A. S., Archer, C. R., Huber, R., Powell, T. K., Lindow, S., Kaiser, M. and Dudler, R. 2008. A plant pathogen virulence factor inhibits the eukaryotic proteasome by a novel mechanism. Nature 452:755-758.

Grütter, M. G. 2000. Caspases: key players in programmed cell death. Curr. Opin. Struct. Biol. 10:649-655.

Hao, L., Hsiang, T. and Goodwin, P. H. 2006. Role of two cysteine proteinases in the susceptible response of Nicotiana benthamiana to Colletotrichum destructivum and the hypersensitive response to Pseudomonas syringae pv. tomato. Plant Sci. 170:1001-1009.

Hatsugai, N., Kuroyanagi, M., Yamada, K., Meshi, T., Tsuda, S., Kondo, M., Nishimura, M. and Hara-Nishimura, I. 2004. A plant vacuolar protease, VPE, mediates virus-induced hypersensitive cell death. Science 305:855-858.

He, R., Drury, G. E., Rotari, V. I., Gordon, A., Willer, M., Tabasum, F., Woltering, E. J. and Gallois, P. 2007. Metacaspase-8 modulates programmed cell death induced by $\mathrm{UV}$ and $\mathrm{H}_{2} \mathrm{O}_{2}$ in Arabidopsis. J. Biol. Chem. 283:774-783.

Hoeberichts, F. A., Ten Have, A. and Woltering, E. J. 2003. A tomato metacaspase gene is upregulated during programmed cell death in Botrytis cinerea-infected leaves. Planta 217:517-522.

Jesenberger, V. and Jentsch, S. 2002. Deadly encounter: ubiquitin meets apoptosis. Nat. Rev. Mol. Cell Biol. 3:112-121.

Jones, J. D. G. and Dangle, J. L. 2006. The plant immune system. Nature 444:323-329.

Kraft, E., Stone, S. L., Ma, L., Su, N., Gao, Y., Lau, O.-S., Deng, X. W. and Callis, J. 2005. Genome analysis and functional characterization of the E2 and ring domain E3 ligase ubiquitination enzymes of Arabidopsis thaliana. Plant Physiol. 139:1597-1611.

Krüger, J., Thomas, C. M., Golstein, C., Dixon, M. S., Smoker, M., Tang, S., Mulder, L. and Jones, J. D. 2002. A tomato cysteine protease required for $\mathrm{Cf}-2$-dependent disease resistance and suppression of autonecrosis. Science 296:744-747.

Kurepa, J. and Smalle, J. A. 2008. Structure, function and regulation of plant proteasomes. Biochimie. 90:324-335.

Kuroyanagi, M., Yamada, K., Hatsugai, N., Kondo, M., Nishimura, M. and Hara-Nishimura, I. 2005. Vacuolar processing enzyme is essential for mycotoxin-induced cell death in Arabidopsis thaliana. J. Biol. Chem. 280:32914-32920.

Lee, S. J., Kelley, B. S., Damasceno, C. M., St John, B., Kim, B. S., Kim, B. D. and Rose, J. K. 2006. A functional screen to characterize the secretomes of eukaryotic pathogens and their hosts in planta. Mol. Plant Microbe Interact. 19:1368-1377.

Lequeu, J., Simon-Plas, F., Fromentin, J., Etienne, P., Petitot, A. S., Blein, J. P. and Suty, L. 2005. Proteasome comprising a betal inducible subunit acts as a negative regulator of NADPH oxidase during elicitation of plant defense reactions. FEBS Lett. 579:4879-4886. 
Li, J., Brader, G. and Palva, E. T. 2008. Kunitz Trypsin Inhibitor: An antagonist of cell death triggered by phytopathogens and fumonisin B1 in Arabidopsis. Mol. Plant. 1:482-495.

Li, Z., Sommer, A., Dingermann, T. and Noe, C. R. 1996. Molecular cloning and sequence analysis of a cDNA encoding a cysteine proteinase inhibitor from sorghum bicolor seedlings. Mol. Gen. Genet. 251:499-502.

Liu, Y., Dammann, C. and Bhattacharyya, M. K. 2001. The matrix metalloproteinase gene $G m \mathrm{MMP} 2$ is activated in response to pathogenic infections in soybean. Plant Physiol. 127:1788-1797.

Luderer, R., Takken, F. L. W., de Wit, P. J. G. M. and Joosten, M. H. A. J. 2002.Cladosporium fulvum overcomes Cf-2-mediated resistance by producing truncated AVR2 elicitor proteins. Mol. Microbiol. 45: 875-884.

Madeo, F., Herker, E., Maldener, C. et al. 2002. A caspase-related protease regulates apoptosis in yeast. Mol. Cell. 9:911-917.

Maidment, J. M., Moore, D., Murphy, G. P., Murphy, G. and Clark, I. M. 1999. Matrix metalloproteinase homologues from Arabidopsis thaliana. J. Biol. Chem. 274:34706-34710.

McGeehan, G., Burkhart, W., Anderegg, R., Becherer, J. D., Gillikin, J. W. and Graham, J. S. 1992. Sequencing and characterization of the soybean leaf metalloproteinase: Structural and functional similarity to the matrix metalloproteinase family. Plant Physiol. 99:1179-1183.

Nagase, H., Woessner, J. F. Jr. 1999. Matrix metalloproteinases. J. Biol. Chem. 274:21491-21494.

Navarre, D. A. and Wolpert, T. J. 1999. Victorin induction of an apoptotic, senescence-like response in oats. Plant Cell 11:237250.

Pak, J. H., Liu, C. Y., Huangpu, J. and Graham, J. S. 1997. Construction and characterization of the soybean leaf metalloproteinase cDNA. FEBS Lett. 404:283-288.

Petitot, A. S., Blein, J. P., Pugin, A. and Suty, L. 1997. Cloning of two plant cDNAs encoding a beta-type proteasome subunit and a transformer-2-like SR-related protein: early induction of the corresponding genes in tobacco cells treated with cryptogein. Plant Mol Biol. 35:261-269.

Rawlings, N. D. and Barrett, A. J. 1999. MEROPS: the peptidase database. Nucleic Acids Res. 27:325-331.

Rawlings, N. D. Morton, F. R. and Barrett, A. J. 2006. MEROPS: the peptidase database. Nucleic Acids Res. 34:D270-272.

Roberts, K. 1994. The plant extracellular matrix: in a new expansive mood. Curr. Opin. Cell Biol. 6:688-694.

Rojo, E., Martín, R., Carter, C., Zouhar, J., Pan, S., Plotnikova, J., Jin, H., Paneque, M., Sánchez-Serrano, J. J., Baker, B., Ausubel, F. M. and Raikhel, N. V. 2004. VPEg exhibits a caspase-like activity that contributes to defense against pathogens. Curr. Biol. 14:1897-1906.

Rooney, H. C., Van't Klooster, J. W., van der Hoorn, R. A., Joosten, M. H., Jones, J. D. and de Wit, P. J. 2005. Cladosporium Avr2 inhibits tomato Rcr3 protease required for Cf-2-dependent disease resistance. Science 308:1783-1786.

Sánchez-Serrano, J. J., Baker, B., Ausubel, F. M. and Raikhel, N. V. 2004. VPEg exhibits a caspase-like activity that contributes to defense against pathogens. Curr. Biol. 14:1897-1906.

Sanmartín, M., Jaroszewski, L., Raikhel, N. V. and Rojo, E. 2005.
Caspases. Regulating death since the origin of life. Plant Physiol. 137:841-847.

Shabab, M., Shindo, T., Gu, C., Kaschani, F., Pansuriya, T., Chintha, R., Harzen, A., Colby, T., Kamoun, S. and van der Hoorn, R. A. 2008. Fungal effector protein AVR2 targets diversifying defenserelated Cys proteases of tomato. Plant Cell 20:1169-1183.

Shindo, T. and van der Hoorn, R. A. 2008. Papain-like cysteine proteases: key players at molecular battlefields employed by both plants and their invaders. Mol. Plant Pathol. 9:119-125.

Simões, I., Faro, R., Bur, D. and Faro, C. 2007. Characterization of recombinant CDR1, an Arabidopsis aspartic proteinase involved in disease resistance. J. Biol. Chem. 282:31358-31365.

Small, J. and Vierstra, R. D. 2004. The ubiquitin 26S proteasome proteolytic pathway. Annu. Rev. Plant Biol. 55:555-590.

Suty, L., Lequeu, J., Lançon, A., Etienne, P., Petitot, A. S. and Blein, J. P. 2003. Preferential induction of 20S proteasome subunits during elicitation of plant defense reactions: towards the characterization of plant defense proteasomes. Int. J. Biochem. Cell Biol. 35:637-650.

Tian, M., Huitema, E., Da cunha, L., Torto-Alalibo, T. and Kamoun, S. 2004. A Kazal-like extracellular serine protease inhibitor from Phytophthora infestans targets the tomato Pathogenesisrelated Protease P69B. J. Biol. Chem. 279: 26370-26377.

Tian, M., Win, J., Song, J., van der Hoorn, R., van der Knaap, E. and Kamoun, S. 2007. A Phytophthora infestans cystatin-like protein targets a novel tomato papain-like apoplastic protease. Plant Physiol. 143:364-377.

Uren, A. G., O'Rourke, K., Aravind, L. A., Pisabarro, M. T., Seshagiri, S., Koonin, E. V. and Dixit, V. M. 2000. Identification of paracaspases and metacaspases: two ancient families of caspase-like proteins, one of which plays a key role in MALT lymphoma. Mol. Cell. 6:961-967.

Van Baarlen, P., Woltering, E. J., Staats, M. and Van Kan, J. A. L. 2007. Histochemical and genetic analysis of host and non-host interactions of Arabidopsis with three Botrytis species: an important role for cell death control. Mol. Plant Pathol. 8:41-54.

van der Hoorn, R. A. L. and Jones, J. D. 2004. The plant proteolytic machinery and its role in defence. Curr. Opin. Plant Biol. 7:400-407.

van der Hoorn, R. A. L. 2008. Plant proteases: From pheotypes to molecular mechanisms. Annu. Rev. Plant Biol. 59:191-223.

van Doorn W. G. and Woltering, E. J. 2004. Senescence and programmed cell death: substance or semantics? J. Exp. Bot. 55:2147-2153.

Watanabe, N. and Lam, E. 2004. Recent advance in the study of caspase-like protease and Bax inhibitor-1 in plants: their possible roles as regulators of programmed cell death. Mol. Plant Pathol. 5:65-70.

Watanabe, N. and Lam, E. 2005. Two Arabidopsis metacaspases AtMCP1b and AtMCP2b are arginine/lysine-specific cysteine proteases and activate apoptosis-like cell death in yeast. $J$. Biol. Chem. 280:14691-14699.

Xia, Y., Suzuki, H., Borevitz, J., Blount, J., Guo, Z., Patel, K., Dixon, R. A. and Lamb, C. 2004. An extracellular aspartic protease functions in Arabidopsis disease resistance signaling. EMBO J. 23:980-988. 